\title{
Colonic tubular adenoma with incidental oxyntic gastric heterotopia
}

\author{
JosÉ-Fernando VAL-BernaL ${ }^{1)}$, MARÍA LUISA CAGIGaL ${ }^{2)}$, MARTA MARÍA MAYORGA ${ }^{2)}$, \\ MARTA MARÍA CUADRADO ${ }^{3)}$, CARLOS RODRIGUEZ-ESCAJA ${ }^{4)}$
}

\author{
1) Department of Medical and Surgical Sciences, University of Cantabria-IDIVAL, Santander, Spain \\ 2) Service of Anatomical Pathology, Marqués de Valdecilla University Hospital-IDIVAL, Santander, \\ Spain \\ 3) Service of Anatomical Pathology, Sierrallana Hospital, Torrelavega, Spain \\ 4) Service of Endoscopy, Sierrallana Hospital, Torrelavega, Spain
}

\begin{abstract}
Oxyntic gastric heterotopia $(\mathrm{GH})$ in the colon is not common. Its presence in a colon tubular adenoma is even rare. A 73-year-old woman with a history of resected colon carcinoma underwent periodical colonoscopies for the removal of tubular adenomas for 12 years. In the last colonoscopy, a sessile, non-ulcerated polyp, centrally depressed, with a smooth surface, measuring $20 \mathrm{~mm}$, located at $50 \mathrm{~cm}$ from the anal verge was excised. A histological study identified a tubular adenoma with focal low-grade dysplasia and ectopic gastric oxyntic epithelium. The GH, composed of parietal and chief cells, and was found incidentally. Oxyntic GH in a tubular adenoma is extraordinarily rare. To the best of our knowledge, there is only one previously published case. The main possible difficulties and/or errors in the diagnosis include a tissue floater or a cross-contaminant. Precise diagnosis of oxyntic $\mathrm{GH}$ is basic for appropriate management. Diagnosis relies on histopathological examination. The immunohistochemical study for mucin 6 (MUC6) can confirm the nature of the epithelium. Oxyntic GH has the potential to produce serious complications including tumor development. However, $\mathrm{GH}$ is considered a benign disease and adenocarcinoma rarely occurs in the heterotopic mucosa. The optimal treatment of oxyntic GH associated with a tubular adenoma is endoscopic complete polypectomy.
\end{abstract}

Keywords: heterotopia, gastric heterotopia, tubular adenoma, heterotopic oxyntic mucosa, colon.

\section{a Introduction}

Gastric heterotopia $(\mathrm{GH})$ consists of the presence of mature gastric mucosa in an anatomical location where it is not normally found. Heterotopia must be differentiated from metaplasia. Metaplasia results in the conversion of one type of differentiated tissue into another. That process occurs in areas of tissue regeneration caused by mechanical damage, inflammation, toxicity, or abnormal hormonal stimulation [1]. GH can be observed throughout the alimentary canal from the nasopharynx and oral cavity to the anus [2,3]. GH has also been described in the pancreatobiliary tract [4-6]. The lesion has even been observed outside the digestive tract, such as the mediastinum [7], scrotum [8], and spinal cord [9, 10]. GH has been reported in children and adults and presents a slight male predominance [2]. Most cases are observed in the esophagus ("the inlet patch"), duodenum, and Meckel's diverticulum $[3,11-13]$. The GH is usually solitary $[2,14]$ and rarely involves the colon, rectum, or anus ("the outlet patch") [2, 15-17]. Thus, Terada, in a study of 3328 biopsies of the gastrointestinal (GI) tract, observed that the frequency of $\mathrm{GH}$ amounted to $8 \%$ in the esophagus, $11 \%$ in the duodenum, and $0 \%$ in the colorectum [12]. In a Chinese study, none of 3504 patients who underwent colonoscopy were diagnosed with $\mathrm{GH}$ [11]. Since the initial description by Ewell \& Jackson [18], less than 50 cases of GH located in the large intestine have been published [19]. Most cases have been described in the rectum [2]. Histopathologically,
GH may show oxyntic-type epithelium, or pyloric-type epithelium [20]. The pathogenesis of the lesion has been considered developmental or acquired depending on the type of epithelium observed [21].

$\mathrm{GH}$ is usually a benign condition. It may be asymptomatic or may present GI symptoms. Awareness of this lesion is clinically relevant as it may produce serious complications. On the other hand, this condition endoscopically can display a neoplastic appearance [3]. Furthermore, the lesion can be associated with a benign [22] or malignant neoplasm $[2,23]$.

$\mathrm{GH}$ is not common in the colonic mucosa but its presence in a colon tubular adenoma is even rare [24].

\section{Aim}

We describe herein the presence of a focus of oxyntic $\mathrm{GH}$ in a tubular adenoma of the colon. To the best of our knowledge, only a previous report has described this type of association [24]. The rarity and potentiality of the lesion justifies the documentation of a new case.

\section{ㅁ Case presentation}

A 73-year-old woman was referred for colonoscopy to our Hospital in August 2020. There was a history of colon carcinoma resected in 2008, and polypectomy of three tubular adenomas with low-grade dysplasia in the transverse colon (55-65 $\mathrm{cm}$ from the anal verge) in 2014. In addition, two colonic tubular adenomas and a

This is an open-access article distributed under the terms of a Creative Commons Attribution-NonCommercial-ShareAlike 4.0 International Public License, which permits unrestricted use, adaptation, distribution and reproduction in any medium, non-commercially, provided the new creations are licensed under identical terms as the original work and the original work is properly cited. 
hyperplastic polyp were excised in 2018 . The colonoscopy revealed two polyps. One was a cecal, sessile tubular adenoma with low-grade dysplasia measuring $3 \mathrm{~mm}$ in diameter. The other was a sessile, non-ulcerated polyp, centrally depressed, with a smooth surface, measuring $20 \mathrm{~mm}$, located at $50 \mathrm{~cm}$ from the anal verge (Figure 1). The case is too recent for a significant clinical follow-up.

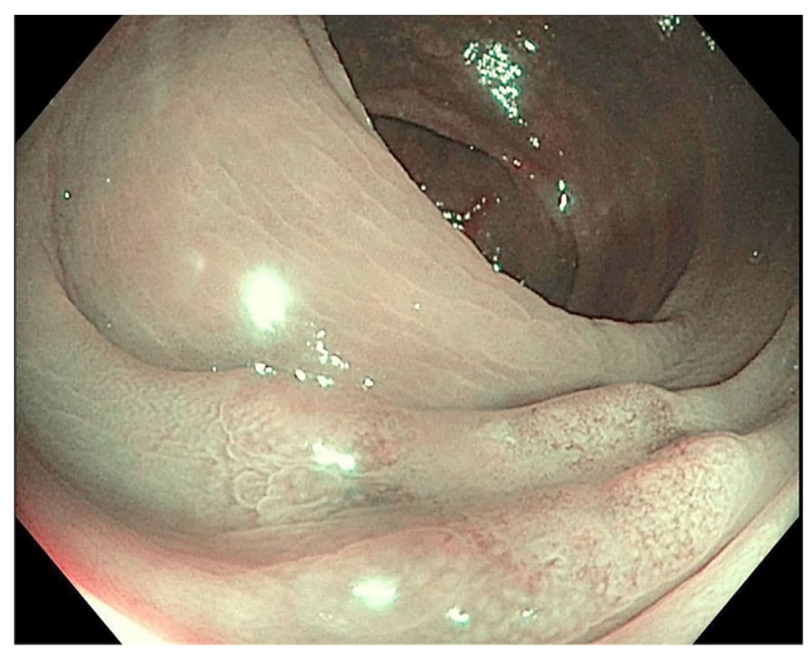

Figure 1 - Endoscopic appearance of the colonic lesion: sessile polyp with central depression.

\section{Histopathological (HP) findings}

The $20 \mathrm{~mm}$ sessile polyp was fixed in $10 \%$ neutral buffered formalin. Representative tissue samples were embedded in paraffin. For routine microscopy, $5 \mu \mathrm{m}$-thick sections were stained with Hematoxylin-Eosin (HE), and the Warthin-Starry method for Helicobacter pylori. Immunohistochemical (IHC) staining was performed using the EnVision FLEX+ Visualization System (Dako, Agilent Technologies, SL, Las Rozas, Madrid, Spain). The IHC reaction was performed using appropriate tissue control for the antibodies utilized. Automatic staining was accomplished on a Dako Omnis stainer (Agilent Technologies, SL). The antibodies used are detailed in Table 1.

Table 1 - IHC antibodies used in this study

\begin{tabular}{ccccc}
\hline Antibody & Source & Clone & Dilution & $\begin{array}{c}\text { Retrieval } \\
\text { solution } \\
\text { pH (Dako) }\end{array}$ \\
\hline MUC2 & Dako & CCP58 & FLEX RTU & High \\
\hline MUC6 & Gennova & CLH5 & $1: 100$ & High \\
\hline Synaptophysin & Dako & SY38 & FLEX RTU & High \\
\hline Chromogranin A & Dako & Polyclonal & FLEX RTU & High \\
\hline
\end{tabular}

Dako (Agilent Technologies, SL, Las Rozas, Madrid, Spain); Gennova Scientific, SL, San José de La Rinconada, Sevilla, Spain; IHC: Immunohistochemical; MUC: Mucin; RTU: Ready-to-use.

Histological examination of this polyp identified a tubular adenoma with focal low-grade dysplasia and ectopic gastric oxyntic epithelium (Figure 2A). This epithelium showed all the elements present in normal orthotopic oxyntic mucosa sharply delimited from the surrounded tubules of the adenoma (Figure 2B). The highly specialized cells formed tightly packed glands including parietal and chief cells. Parietal cells were plump, round to oval shaped, pale red, slightly granular cytoplasm. Chief cells were columnar with denser, darker purple cytoplasm. Both types of cells showed small, eccentric, round, uniform nuclei (Figure 3A). H. pylori colonization was not observed. On immunohistochemistry, the oxyntic cells were stained for mucin (MUC) 6 and were nonreactive for MUC2. The MUC6 immunoexpression was cytoplasmic (Figure 3B). Synaptophysin and chromogranin A revealed very scant neuroendocrine cells between parietal and chief cells. Epithelial dysplasia or malignancy was not detected in the specialized oxyntic mucosa. The $\mathrm{GH}$ measured $1 \mathrm{~mm}$ in maximum diameter.

The IHC study confirmed the nature of the epithelium observed with ordinary staining.

\section{ㅁ Discussions}

$\mathrm{GH}$ has been reported at various locations of the GI tract including the esophagus $[11,12]$, small intestine $[11,12,25]$, colon, rectum, anus [2, 3, 15-17, 21, 26], vermiform appendix [27], gallbladder [4], hilar bile duct [5], and ampulla of Vater [6]. We have planned the discussion in two parts: $(A)$ and $(B)$.

\section{(A) $\mathrm{GH}$ in the colon}

The colon is the least commonly affected portion of the digestive tube. Thus, less than 20 cases of GH have been reported in the colon [2, 17, 26, 28-39]. GH can be observed in all age groups. The median age is 54 years (range four months-73 years) [2]. It is a bit more common in males (M:F ratio, 1.5:1) [2]. Exceptionally, the lesion is multifocal and may be associated with intestinal and extraintestinal anomalies including vertebral and digital anomalies [26].

Two histological types of GH have been identified: oxyntic and pyloric [20]. Oxyntic (fundic) heterotopia is characterized by a complete mucosal thickness of specialized gastric glands consisting of chief and parietal cells, and a surface lined by gastric foveolar epithelium. Oxyntic heterotopia is believed to represent a developmental anomaly. Pyloric heterotopia is identified by the presence of only gastric foveolar epithelium with absence of specialized gastric glands. This type of heterotopia is believed to be acquired because of inflammation or infection [21]; it, therefore, meets the criteria for gastric metaplasia [12]. Most (85\%) reported cases are of the oxyntic type [2].

$\mathrm{GH}$ can manifest as hematochezia, and non-specific abdominal symptoms, such as episodic diarrhea or abdominal pain, but most (55\%) cases are asymptomatic [2]. Endoscopic appearance may include a prominent mucosal fold, an erythematous mucosa, a diverticulum, an ulcer, or a sessile or pedunculated polyp [3, 29, 40]. Endoscopically, the lesion can even be mistaken for a superficial neoplasm [3]. GH may cause important complications, such as colonic bleeding, iron deficiency anemia [3, 20], intestinal perforation [41], intussusception [42], stricture [20], presence of H. pylori organisms [2], and development of pyloric gland adenoma $[2,22]$ or colonic adenocarcinoma $[2,23]$. The risk of malignant transformation of $\mathrm{GH}$ is currently not well established [2, 23]. GH is considered a benign disease and adenocarcinoma rarely occurs in the heterotopic mucosa. The malignant transformation could be preceded by progressive dysplasia [2]. The oxyntic GH has morphological and functional features similar to the normal fundic mucosa. In fact, some symptoms and complications are due to the corrosive effect of the acid secretion. Symptoms and complications are reasonably related to the size and location of the GH [20]. 

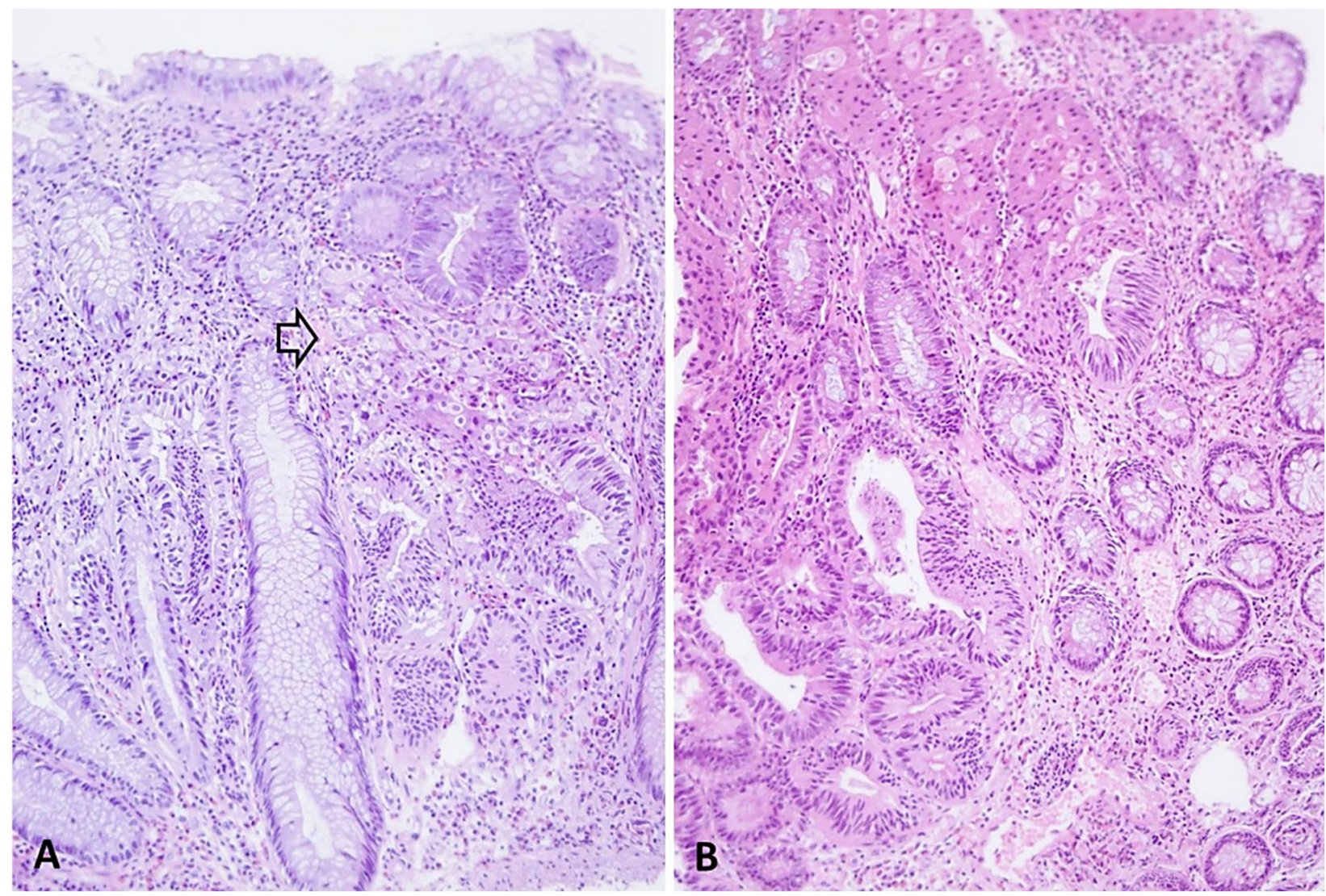

Figure 2 - Low-grade dysplasia tubular adenoma of the colon with oxyntic GH: (A) Low power image - the arrow points to a focus of $\mathrm{GH}$; (B) Medium power image showing dysplastic tubules and oxyntic cells. HE staining: (A and B) $\times 200$. GH: Gastric heterotopia; HE: Hematoxylin-Eosin.
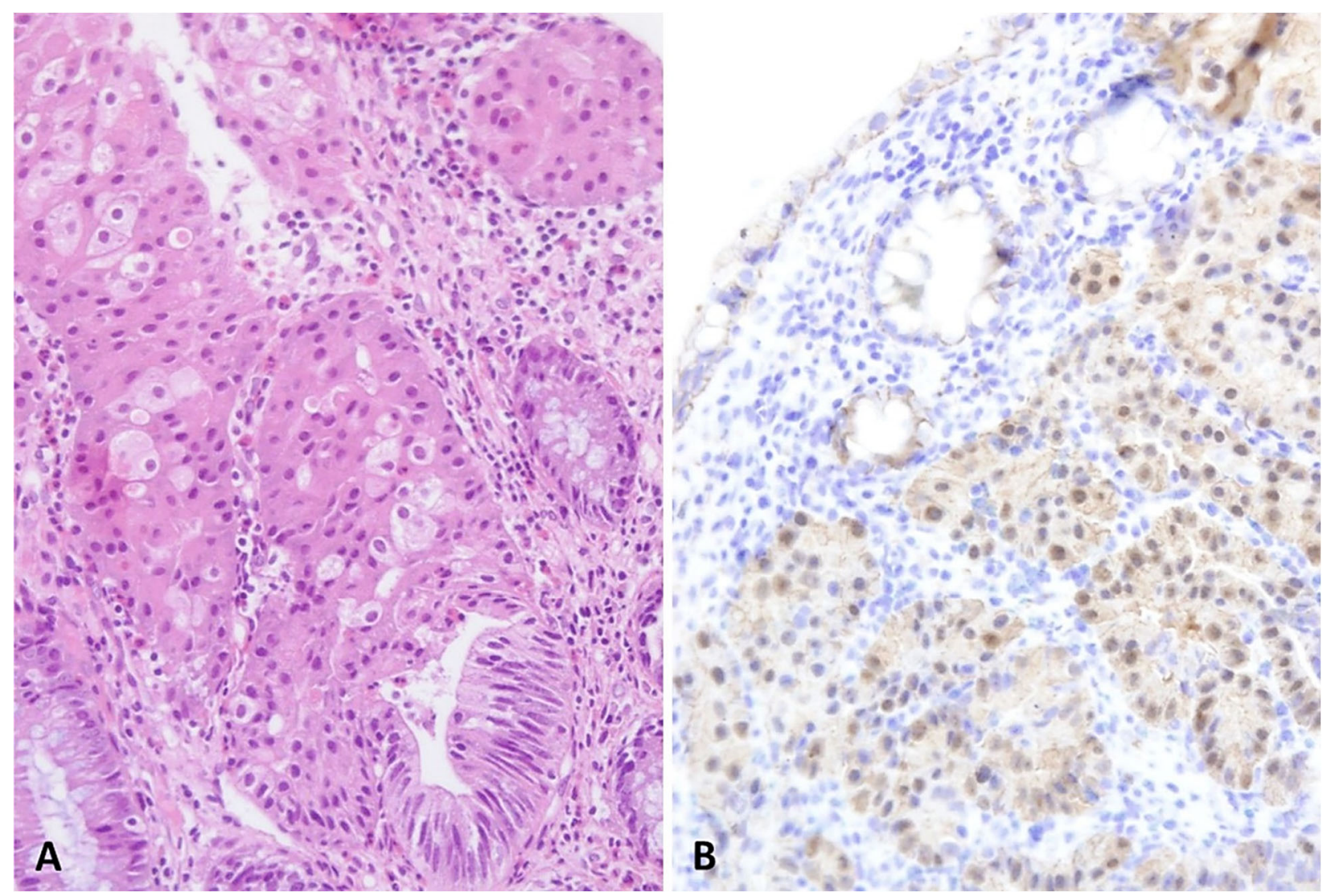

Figure 3 - Oxyntic GH: (A) Parietal and chief cells are present between the tubules of the adenoma; (B) Oxyntic cells show positive cytoplasmic reactivity for MUC6. HE staining: (A) $\times 400$. Anti-MUC6 antibody immunomarking: $(B) \times 400$. GH: Gastric heterotopia; HE: Hematoxylin-Eosin; MUC6: Mucin 6. 
The pathogenesis of GH is uncertain. The lesion has been considered congenital or acquired [2, 21, 23]. According to the literature, the mechanisms of GH pathogenesis probably are related to $(i)$ inborn error during embryogenesis; (ii) abnormal regenerative process following mucosa injury due to infectious or inflammatory conditions; (iii) erroneous differentiation of pluripotent endodermal stem cells in the intestine. The congenital theory suggests that $\mathrm{GH}$ is the result of an inborn error during embryogenesis. Cases observed in young patients associated with congenital anomalies have suggested that the lesion is congenital $[26,28]$. This process could be the result of dislocation of the specialized gastric epithelium during organogenesis in embryonic development. The acquired theory considers that GH is the result of an abnormal regenerative process following mucosa injury due to infectious or inflammatory conditions [23]. It would be due to a process of differentiation reprogramming of reserve cells in the colonic crypts with absence of specialized gastric mucosa. However, the scarcity of development GH following mucosal injury argues against that interpretation [2]. The stem cell hypothesis proposes that $\mathrm{GH}$ is a consequence of the erroneous differentiation of pluripotent endodermal stem cells in the intestine. The cells lining the primitive intestinal tube would be capable of differentiating into any of the types of epithelia normally present at any other level [21]. Caudal type homeobox 2 $(C D X 2)$ and other homeobox genes have been involved in the control of cell differentiation in the intestinal epithelium. A local injury could cause deregulation or reactivation of these genes resulting in gastric differentiation in the colorectal segment $[23,26,43,44]$. This last hypothesis is considered the most reasonable theory.

\section{(B) $\mathrm{GH}$ in colonic tubular adenoma}

Oxyntic heterotopia in a tubular adenoma is extraordinarily rare. In fact, to our knowledge, there is only one previously published case [12]. The patient, a 64year-old female was referred for colonoscopy because of fecal occult blood. Endoscopy revealed a $6 \mathrm{~mm}$ wide polyp with a smooth surface arising in the distal descending colon at $50 \mathrm{~cm}$ from the anal verge. HP study of the polyp revealed a tubulovillous adenoma with an area of ectopic oxyntic epithelium. One year later the patient was free of lesions.

In the previous report and the present case, polypectomy was both diagnostic and curative.

Recently, Dabir et al. [45] reviewed the incidental morphological findings that can be found in colorectal adenomas. That study describes diverse features that may present diagnostic challenges and questions in clinical management. The morphological features include Paneth cell metaplasia, squamous metaplasia, clear cell metaplasia, osseous metaplasia, neuroendocrine differentiation, and signet-ring cell-like lesion. The spectrum of those incidental associated lesions is herein extended by describing a case of oxyntic (fundic) GH in a tubular adenoma of an elderly patient.

The main difficulties and/or errors in the diagnosis include the transfer of a tissue floater or tissue contaminant to the slide during tissue processing [46-48]. Recut of the paraffin block and observing deeper levels of the tissue usually solve the problem. However, if microscopy alone cannot distinguish contamination deoxyribonucleic acid (DNA)-based molecular identity testing (molecular DNA fingerprinting analysis) of the extraneous, tissue can be necessary $[46,48]$.

\section{ㅁ Conclusions}

We report the second case of oxyntic GH arising from a colonic tubular adenoma. These two cases suggest that this association is not coincidental. Accurate diagnosis of oxyntic GH is necessary for appropriate management. A potential source for diagnostic error is a tissue floater or a cross-contaminant. The diagnosis rests on HP examination. Immunohistochemistry for MUC6 can confirm that the heterotopic mucosa is oxyntic. The lesion has the potential to produce serious complications including tumor development. Treatment of oxyntic GH associated with a tubular adenoma is endoscopic complete polypectomy.

\section{Conflict of interests}

The authors declare no conflict of interests.

\section{Compliance with ethical standards}

No Ethics Committee approval is required in our institution for a case report involving a single patient.

\section{Consent}

Written informed consent was obtained from the patient for publication of this case report and all accompanying images.

\section{Funding}

This study was not funded externally.

\section{References}

[1] Wright NA. Cell growth, size, and differentiation. In: McGee JO'D, Isaacson PG, Wright NA, Dick HM, Slack MPE (eds). Oxford Textbook of Pathology. Volume 1: Principles of Pathology. Oxford University Press, Oxford, UK, 1992, 555-568. https:// www.amazon.com/Oxford-Textbook-Pathology-Principles-

Publications/dp/0192619721

[2] Mannan AASR, Vieth M, Khararjian A, Khandakar B, LamHimlin D, Heydt D, Bhaijee F, Venbrux HJ, Byrnes K, Voltaggio L, Barker N, Yuan S, Montgomery EA. The outlet patch: gastric heterotopia of the colorectum and anus. Histopathology, 2018, 73(2):220-229. https://doi.org/10.1111/ his.13632 PMID: 29667709

[3] lacopini F, Gotoda T, Elisei W, Rigato P, Montagnese F, Saito $Y$, Costamagna G, lacopini G. Heterotopic gastric mucosa in the anus and rectum: first case report of endoscopic submucosal dissection and systematic review. Gastroenterol Rep (Oxf), 2016, 4(3):196-205. https://doi.org/10.1093/gastro/gow 006 PMID: 27103738 PMCID: PMC4976682

[4] Hayama S, Suzuki Y, Takahashi M, Hazama K, Fujita M, Kondo S, Katoh $\mathrm{H}$. Heterotopic gastric mucosa in the gallbladder: report of two cases. Surg Today, 2010, 40(8):783-787. https://doi.org/10.1007/s00595-009-4269-1 PMID: 20676865

[5] Fukuda S, Mukai S, Shimizu S, Kouchi M, Fujisaki S, Takahashi M, Sakimoto H, Eto T, Takahashi M, Nishida T. Heterotopic gastric mucosa in the hilar bile duct mimicking hilar cholangiocarcinoma: report of a case. Surg Today, 2013, 43(1):91-95. https://doi.org/10.1007/s00595-012-0221-x PMID: 22706785

[6] Jarry J Jr, Rault A, Sa Cuhna A, Collet D, Masson B. Acute recurrent pancreatitis by heterotopic fundic mucosa at the ampulla of Vater. Pancreas, 2009, 38(3):351-353. https:// doi.org/10.1097/MPA.0b013e3181888feb PMID: 19307936 
[7] Willis RA. Some unusual developmental heterotopias. $\mathrm{Br}$ Med J, 1968, 3(5613):267-272. https://doi.org/10.1136/bmj. 3.5613.267 PMID: 5661665 PMCID: PMC1986298

[8] Khan MA, Fitzgerald RJ. Heterotopic gastric tissue in the scrotum. J Urol, 1996, 155(6):2061. https://doi.org/10.1097/ 00005392-199606000-00089 PMID: 8618336

[9] Knight G, Griffiths T, Williams I. Gastrocystoma of the spinal cord. Br J Surg, 1955, 42(176):635-638. https://doi.org/10. 1002/bjs. 18004217612 PMID: 13240076

[10] Kantrowitz LR, Pais MJ, Burnett K, Choi B, Pritz MB. Intraspinal neurenteric cyst containing gastric mucosa: CT and MRI findings. Pediatr Radiol, 1986, 16(4):324-327. https:// doi.org/10.1007/BF02386874 PMID: 3725451

[11] Yu L, Yang Y, Cui L, Peng L, Sun G. Heterotopic gastric mucosa of the gastrointestinal tract: prevalence, histological features, and clinical characteristics. Scand J Gastroenterol, 2014, 49(2):138-144. https://doi.org/10.3109/00365521.2013. 860558 PMID: 24279774

[12] Terada T. Heterotopic gastric mucosa of the gastrointestinal tract: a histopathologic study of 158 cases. Pathol Res Pract, 2011, 207(3):148-150. https://doi.org/10.1016/j.prp.2010.12. 004 PMID: 21242038

[13] Chong VH. Clinical significance of heterotopic gastric mucosal patch of the proximal esophagus. World J Gastroenterol, 2013, 19(3):331-338. https://doi.org/10.3748/wjg.v19.i3.331 PMID: 23372354 PMCID: PMC3554816

[14] Fang Y, Chen L, Chen DF, Ren WY, Shen CF, Xu Y, Xia YJ, Li JW, Wang P, Zhang AR, Shao SZ, Yu XN, Peng GY, Fang DC. Prevalence, histologic and clinical characteristics of heterotopic gastric mucosa in Chinese patients. World $J$ Gastroenterol, 2014, 20(46):17588-17594. https://doi.org/10 3748/wjg.v20.i46.17588 PMID: 25516674 PMCID: PMC 4265621

[15] Sousa J, Cabezuelo L, Rodrigues A, Costa N, Cipriano MA Heterotopia gástrica no recto. Uma entidade rara [Gastric heterotopia of rectum: a rare entity]. Acta Med Port, 2010, 23(6):1151-1154. PMID: 21627893

[16] Dinarvand P, Vareedayah AA, Phillips NJ, Hachem C, Lai J. Gastric heterotopia in rectum: a literature review and its diagnostic pitfall. SAGE Open Med Case Rep, 2017, 5: 2050313X17693968. https://doi.org/10.1177/2050313X1769 3968 PMID: 28321304 PMCID: PMC5347492

[17] Taylor FM 3rd, Swank RI 2nd. Epithelial heterotopia in the colon of a child: a case presentation and review of the literature. J Fla Med Assoc, 1982, 69(9):788-791. PMID: 6757379

[18] Ewell GH, Jackson RH. Aberrant gastric mucosa in the rectum with ulceration and hemorrhage. Wis Med J, 1939, 38:641643.

[19] Gonzalez RS. Gastric heterotopia. PathologyOutlines.com website. https://www.pathologyoutlines.com/topic/colongastric heterotopia.html, accessed: March 16, 2021.

[20] Nasir A, Amateau SK, Khan S, Simpson RW, Snover DC, Amin K. The many faces of intestinal tract gastric heterotopia; a series of four cases highlighting clinical and pathological heterogeneity. Hum Pathol, 2018, 74(4):183-187. https:// doi.org/10.1016/j.humpath.2018.01.003 PMID: 29320750

[21] Wolff M. Heterotopic gastric epithelium in the rectum: a report of three new cases with a review of 87 cases of gastric heterotopia in the alimentary canal. Am J Clin Pathol, 1971, 55(5):604-616. https://doi.org/10.1093/ajcp/55.5.604 PMID: 5090217

[22] Vieth M, Kushima R, de Jonge JPA, Borchard F, Oellig F, Stolte M. Adenoma with gastric differentiation (so-called pyloric gland adenoma) in a heterotopic gastric corpus mucosa in the rectum. Virchows Arch, 2005, 446(5):542-545. https:// doi.org/10.1007/s00428-005-1242-2 PMID: 15838648

[23] Ko H, Park SY, Cha EJ, Sohn JS. Colonic adenocarcinoma arising from gastric heterotopia: a case study. Korean J Pathol, 2013, 47(3):289-292. https://doi.org/10.4132/KoreanJPathol. 2013.47.3.289 PMID: 23837024 PMCID: PMC3701827

[24] Cappell MS. Colonic tubulovillous adenoma associated with gastric heterotopia. N J Med, 1995, 92(8):512-515. PMID: 7675332

[25] Jimenez JC, Emil S, Steinmetz B, Romansky S, Weller M. Recurrent gastrointestinal tract bleeding secondary to jejunal gastric heterotopia. J Pediatr Surg, 2005, 40(10):1654-1657. https://doi.org/10.1016/j.jpedsurg.2005.06.010 PMID: 16227002
[26] Murray FE, Lombard M, Dervan P, Fitzgerald RJ, Crowe J. Bleeding from multifocal heterotopic gastric mucosa in the colon controlled by an H2 antagonist. Gut, 1988, 29(6):848-851. https://doi.org/10.1136/gut.29.6.848 PMID: 3290067 PMCID: PMC1433722

[27] Droga BW, Levine S, Baber JJ. Heterotopic gastric and esophageal tissue in the vermiform appendix. Am J Clin Pathol, 1963, 40(2):190-193. https://doi.org/10.1093/ajcp/40.2.190 PMID: 14064868

[28] Dubilier LD, Caffrey PR, Hyde GL. Multifocal gastric heterotopia in a malformation of the colon presenting as a megacolon. Am J Clin Pathol, 1969, 51(5):646-653. https://doi.org/10. 1093/ajcp/51.5.646 PMID: 4888612

[29] Duran Alvarez MA, Tafur Sanchez CN. Polypoid gastric heterotopia of colon. GE Port J Gastroenterol, 2020, 27(1): 65-67. https://doi.org/10.1159/000500609 PMID: 31970247 PMCID: PMC6959108

[30] Aterman K, Abaci F. Heterotopic gastric and esophageal tissue in the colon. Am J Dis Child, 1967, 113(5):552-559. https://doi.org/10.1001/archpedi.1967.02090200084007 PMID: 6024226

[31] Burne JC. Pancreatic and gastric heterotopia in a diverticulum of the transverse colon. J Pathol Bacteriol, 1958, 75(2):470471. https://doi.org/10.1002/path.1700750229 PMID: 13576332

[32] Engel W. [Gastric mucosa heterotopy in a true colon diverticulum]. Chirurg, 1980, 51(4):247-249. PMID: 7408571

[33] Duphare H, Nijhawan S, Rana S, Bhargava DK. Heterotopic gastric and pancreatic tissue in large bowel. Am J Gastroenterol, 1990, 85(1):68-71. PMID: 2404405

[34] Jacques J, Projetti F, Legros R, Valgueblasse V, Sarabi M, Carrier P, Fredon F, Bouvier S, Loustaud-Ratti V, Sautereau D. Obscure bleeding colonic duplication responds to proton pump inhibitor therapy. World J Gastroenterol, 2013, 19(35):59405942. https://doi.org/10.3748/wjg.v19.i35.5940 PMID: 24124344 PMCID: PMC3793152

[35] Sakiyama T, Tabata H, Nishimata $Y$, Nishimata H, Arima T, Maenohara S. [Duplication of ascending colon with heterotopic gastric mucosa - report of a case]. Nihon Shokakibyo Gakkai Zasshi, 1995, 92(3):241-245. PMID: 7731094

[36] Madro A, Celinski K, Prozorow-Krol B, Lozowski CT, Buk L, Swatek J, Pilat J, Slomka M. Colonic duplication with heterotopy of gastric mucosa. Endoscopy, 2013, 45(Suppl 2 UCTN):E153-E154. https://doi.org/10.1055/s-0032-1326463 PMID: 23716108

[37] Venkatesh K, Cohen M, Akobeng A, Ashok D, Abou-Taleb A, Evans C, Howarth K, Taylor C, Thomson M. Diagnosis and management of the first reported case of esophageal, gastric, and small-bowel heterotopia in the colon, using confocal laser endomicroscopy. Endoscopy, 2009, 41(Suppl 2):E58. https://doi.org/10.1055/s-2008-1077771 PMID: 19319780

[38] Coyne J. Bifocal intestinal gastric heterotopia involving the duodenum and colon: a case report. Colorectal Dis, 2013, 15(1):e64. https://doi.org/10.1111/j.1463-1318.2012.03041.x PMID: 22487021

[39] García-Campos M, Giner F, Bustamante-Balen M. Appearances can be deceiving: a case of intestinal metaplasia and heterotopic gastric mucosa in colon. Dig Endosc, 2019, 31(6):717. https://doi.org/10.1111/den.13477 PMID: 31269304

[40] Srinivasan R, Loewenstine H, Mayle JE. Sessile polypoid gastric heterotopia of rectum: a report of 2 cases and review of the literature. Arch Pathol Lab Med, 1999, 123(3):222224. https://doi.org/10.5858/1999-123-0222-SPGHOR PMID: 10086510

[41] Lambert MP, Heller DS, Bethel C. Extensive gastric heterotopia of the small intestine resulting in massive gastrointestinal bleeding, bowel perforation, and death: report of a case and review of the literature. Pediatr Dev Pathol, 2000, 3(3):277280. https://doi.org/10.1007/s100249910036 PMID: 10742416

[42] Anand P, Singh S, Sarin N. Intussusception caused by heterotopic gastric mucosa in small intestine: a case report. J Med Case Rep, 2017, 11(1):258. https://doi.org/10.1186/ s13256-017-1425-x PMID: 28893301 PMCID: PMC5594578

[43] Sauer CG, Bickston SJ, Borowitz SM. Gastric heterotopia of the rectum. J Pediatr Gastroenterol Nutr, 2010, 50(3):329333. https://doi.org/10.1097/MPG.0b013e3181a1c476 PMID: 19668007

[44] Beck F, Chawengsaksophak K, Waring P, Playford RJ, Furness JB. Reprogramming of intestinal differentiation and 
intercalary regeneration in $\mathrm{Cd} 22$ mutant mice. Proc Natl Acad Sci U S A, 1999, 96(13):7318-7323. https://doi.org/10.1073/ pnas.96.13.7318 PMID: 10377412 PMCID: PMC22083

[45] Dabir PD, van der Post RS, Nagtegaal ID. Incidental morphological findings in colorectal adenomas. Histopathology, 2021, 78(3):348-357. https://doi.org/10.1111/his.14263 PMID: 32981102 PMCID: PMC7894322

[46] Hunt JL. Identifying cross contaminants and specimen mixups in surgical pathology. Adv Anat Pathol, 2008, 15(4):211217. https://doi.org/10.1097/PAP.0b013e31817bf596 PMID: 18580097
[47] Platt E, Sommer P, McDonald L, Bennett A, Hunt J. Tissue floaters and contaminants in the histology laboratory. Arch Pathol Lab Med, 2009, 133(6):973-978. https://doi.org/10. 5858/133.6.973 PMID: 19492892

[48] Layfield LJ, Witt BL, Metzger KG, Anderson GM. Extraneous tissue: a potential source for diagnostic error in surgical pathology. Am J Clin Pathol, 2011, 136(5):767-772. https:// doi.org/10.1309/AJCP4FFSBPHAU8IU PMID: 22031316

\section{Corresponding author}

José-Fernando Val-Bernal, Professor, MD, PhD, Department of Medical and Surgical Sciences, University of Cantabria, Avda. Cardenal Herrera Oria s/n, 39011 Santander, Spain; Phone +34 942 315098, Fax +34 942315952 , e-mail: fernando.val@unican.es

Received: December 11, 2020

Accepted: August 17, 2021 